\title{
Urban diversity and the production of public space in Budapest
}

\author{
Lajos BOROS ${ }^{1}$, Szabolcs FABULA, DÁniel HORVÁTH and Zoltán KOVÁCS²
}

\begin{abstract}
Public spaces are spaces for representation of individuals, social groups, ideologies, values, cultures. At the same time, public spaces are commodified and "disneyfied" in capitalism, thus, the creation of a homogeneous, "desirable" spatial form and use of public space is often intended. Therefore, their production is characterised by constant rivalries and struggles and causes social conflicts. In addition, the production of public spaces in post-socialism has distinct development paths which is often characterised by contradicting traditions and objectives regarding the spatial form and the everyday practices taking place there. These contradictions create conflicts between various individuals, social groups, actors of urban policies etc. The aim of the paper is to investigate how urban social diversity is (re)presented in the public spaces of the $8^{\text {th }}$ district of Budapest, Józsefváros. Which groups and values are more visible than others? How do local people use public spaces? The research is based on the content analysis of policy documents and interviews conducted with local residents of Józsefváros - one of the most diverse districts of Budapest. According to our results, the fragmented nature of the local society is reflected in the use of public space: diversity is present between the public spaces and not within them. Furthermore, some of the recent developments support the homogenisation of values and behaviours in public spaces.
\end{abstract}

Keywords: public space, social diversity, hyper-diversity, social cohesion, post-socialism, Budapest, Józsefváros

\section{Introduction}

Due to the effects of globalisation and intensifying migration contemporary cities tend to become increasingly diverse in terms of ethnicity, culture, lifestyles, identities, values, ideologies and attitudes. The different dimensions of diversity intersect in multiple ways within and between groups (TASAN-KoK, T. et al. 2014). These processes create complex and dynamic urban societies with changing dividing lines and interactions.

Because of their complexity the everyday realities of these diverse societies is difficult to analyse. Neighbourhoods are often perceived and analysed as residential places with special attention to segregation, social bonds and life chances. However, a growing body of literature suggests that neighbourhoods and place of residence should not be the only analytical units when researching social relations (VAn KeMPen, R. and WIssINK, B. 2014). There is strong empirical evidence that diverse neighbourhoods do not mean necessarily that there are diverse social networks among residents (ATKINSON, R. and Kintrea, K. 2000; Van Beckhoven, E. and Van Kempen, R. 2003; Lees, L. 2008; BlokLAND, T. and VAN EIJK, G. 2010; WIssinK, B. and Hazelzet, A. 2012).

Other places, such as workplace, sites of consumption, schools, public spaces can be

\footnotetext{
${ }^{1}$ Department of Economic and Social Geography, Faculty of Science and Informatics, University of Szeged. H-6701 Szeged, PO. Box 650. E-mail: borosl@geo.u-szeged.hu

${ }^{2}$ Geographical Institute, Research Centre for Astronomy and Earth Sciences, Hungary Academy of Sciences, H-1112 Budapest, Budaörsi út 45; Department of Economic and Social Geography, Faculty of Science and Informatics, University of Szeged. H-6701 Szeged, PO. Box 650. E-mail: zkovacs@iif.hu
} 
equally important for establishing contacts, because of proximity, similarity of interests, frequency of encounters etc. (Peters, K and de HaAn, H. 2011; Van Kempen, R. and Wissink, B. 2014). These places can be both located in and outside of the neighbourhood, shaping the spatial activities of local residents. Therefore, social interactions, relations, bonds are significantly influenced by the places (and the flows between them) where residents spend their time: spaces of work, family life and free time. These activities are not fixed in space, instead they are characterised by mobility within uneven networks (SHELLER, M. and URRY, J. 2006; URRY, J. 2007). Thus, to understand the relations in a diverse society we have to analyse the action spaces of people: where they work, live, spend their free time etc. Public spaces are among the most important elements of activity spaces where multiple activities and encounters take place.

The aim of this paper is to analyse the use of public spaces in a highly diverse neighbourhood of Budapest, called Józsefváros. Our primary research questions are as follows: How diversity is (re)presented in those spaces? Who use the public spaces in Józsefváros and for what purposes? What kinds of conflicts emerge regarding the use of public space?

\section{Research methodology}

This research was carried out in Józsefváros which is one of the 23 independent district municipalities of Budapest (Figure 1). The district can be further subdivided into 11 quarters based on their history, built environment or social milieu (Figure 2). Among them the Magdolna and Orczy Quarters are the most deprived areas.

Despite its relatively small territory $(6.85$ $\mathrm{km}^{2}$ ), the district is socially and culturally one of the most diverse areas of the city. The population of Józsefváros is 76,250 (2011) among them the proportion of non-Hungarian ethnic groups is 11.9 per cent - which is rela-

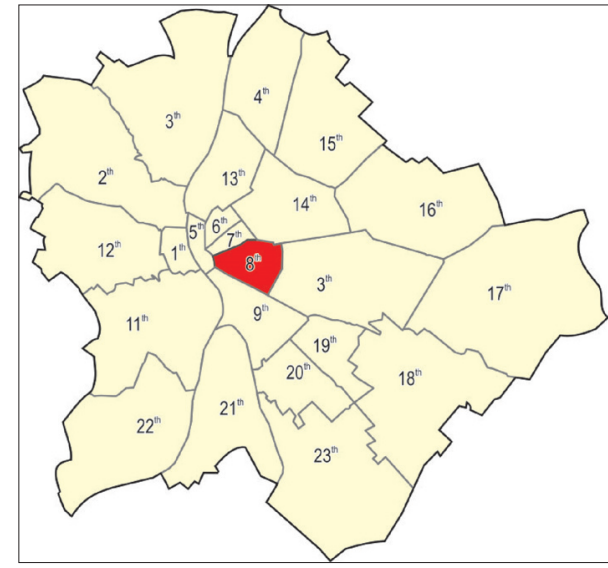

Fig. 1. Location of the case study area within Budapest. Source: edited by the authors

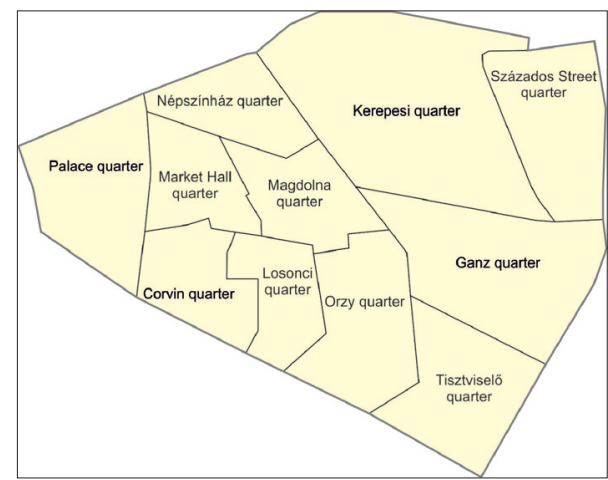

Fig. 2. The quarters within Józsefváros. Source: edited by the authors

tively high by Hungarian comparison. The Gypsy/Roma is the largest ethnic minority group and in some parts of the district they comprise around 50 per cent of the local inhabitants. There are significant South Eastern Asian and African communities in Józsefváros as this is a popular destination for international migrants [1]. Furthermore, Józsefváros has a 'springboard' function within Budapest: it offers affordable housing for those who move to the city. Thus, the local population is ever-changing due to the influx of new residents from both Hungary and abroad. There is also a large number of homeless people and poor households in the 
area. The negative image of Józsefváros is slowly changing as a result of ongoing urban regeneration programmes, gentrification and 'studentification'. Therefore, the area is very diverse with regards social status, ethnic and cultural identity, strength and forms of place attachment, lifestyles etc. The various aspects (social, architectural, cultural etc.) of diversity of the district is considered as an asset in the local development documents.

This paper is mainly based on in-depth interviews conducted with residents of the district. Altogether 50 interviews were held between September 2014 and March 2015 as the part of the Divercities project, financed by the $7^{\text {th }}$ Framework Programme of the EU. The questions focused on the life of the respondents; their career, experiences, their social relations, everyday activities and their relation to Józsefváros. The interview partners were chosen with a snowballing method with the help of key informants (e.g. locals living in the district for decades, representatives of homeowners' associations or civil organisations) from the area. The participation in the research was voluntary. We intended to reflect the diverse nature of the local society in the sample, and to include interviewees with different age, residential, ethnic, cultural, occupational background. Data on ethnic background are based on the selfidentification of the respondents. According to these figures the sample is comprised predominantly by ethnic Hungarians; approximately one-fourth of the interviewees (13) reported on at least one ethnicity other than Hungarian. Regarding their country of origin, 8 were foreign born; they are mainly from the neighbouring countries, namely Slovakia and Romania.

In addition to the interviews, local and national policy documents were also analysed to identify the most important aims related to the development of public spaces. These documents were collected from the publicly available sources, mainly from the homepages of related institutions. No sampling was applied in this case - all available documents were analysed.

\section{Diversity and public space}

Several concepts have been used so far to grasp the complexity of urban societies: multiculturalism, inter-culturalism, diversity, super-diversity etc. One of the key concepts of this study is hyper-diversity (TASAN-KoK, T. et al. 2014) which refers to the increasing diversification of population in various terms: ethnicity, socio-economic status, lifestyles, opportunities and activities. With this broad conceptualisation, hyper-diversity aims to move beyond the previous approaches which often tend to focus on ethnicity or nationality. Traditional approaches assumed that a person's position within the society is directly influenced by his/her ethnic or cultural background, and other socio-economic aspects attached to it. But nowadays there is a growing status discrepancy, and different members of the same family can have very different status within the society. People belonging to the same social or ethnic group may have quite different attitudes with respect to school, work, parents and towards other groups. They may have also very different daily and life routines, activity spaces. There are no clear and simple dividing lines: various interactions can emerge between the dimensions of diversity

Hyper-diversity is a result of the intensifying international migration, the diversification of countries of origin (Vertovec, S. 2007), increasing population mobility within countries and cities (Syrett, S. and Sepulveda, L. 2011), new political processes and structures, changing identities (Castells, M. 2009; Cantle, T. 2012), the neoliberal deregulation processes, the increased connectivity of global cities (Dudás, G. and Pernyész, P. 2011), the intensifying information flows between various groups and places and several other factors.

The concept of hyper-diversity also emphasises the possibilities related to the diverse nature of society: it can contribute to social cohesion and social mobility through the acceptance of otherness and different forms of mutual help and support. In addition, diversity can also enhance economic performance 
according to the concept because of the available social capital, the increased chances of networking, increased productivity and competitive advantages (NATHAN, M. 2006; ErAydin, A. et al. 2010; Syrett, S. and Sepulveda, L. 2011; TASAN-KoK, T. et al. 2014).

As it was mentioned above, activity spaces have a special significance in the integration of hyper-diverse societies, thus, public spaces are essential to realise the potentials related to diverse urban societies. The definitions of public space often focus on ownership and accessibility, claiming that public spaces are commonly owned, accessible spaces (VEDRÉdi, K. 2014). But due to the recent privatisation of public spaces there is no clear divide between publicly and privately owned spaces anymore. Furthermore, probably no public space was accessible equally to everyone in the history - there were always formal and informal restrictions, rules regarding the use of streets, squares, parks etc. Therefore, public space is an ideal type of space which has never been fully achieved (Mitchell, D. 1995; Harvey, D. 2005).

Other approaches focus on the functions and ownership of public spaces instead. However, focusing on ownership can also be misleading, since privately owned places can also function as public spaces - see the examples of malls, stadiums, beaches etc. Therefore, the definition of public spaces should focus rather on their role in the society; hence they are places of social interaction, and spaces of and for representations. Public spaces are 'where the social and cultural rules governing public behaviour predominate' (Mitchell, D. and Stahli, A. 2009, 511). These spaces include streets, squares, malls, parks, sidewalks, cafes, playgrounds etc. Several studies (e.g. Mitchell, D. 1995, 2003; SEnNetT, R. 2002) connect public space with the idea of public sphere, developed by Habermas, J. (1989). According to these approaches, public space is the place of free communication, gathering or interaction, therefore, it is a necessary prerequisite of democracy (Calhoun, C. 1992; Mitchell, D. 1995, 2003; NielsEN, S. 2013). But according to
Sennett, R. (2002) public space is constantly eroded by private interests, thus, the democratic character of society is jeopardised.

In addition to their political significance, public spaces or places of consumption create the sense of belonging and comfort - even without direct social contact, through the casual encounters with familiar faces and environments (Goffman, E. 1959; Curley, A.M. 2010; Blokland, T. and NAst, J. 2014). Encountering with foreigners can contribute to the growth of tolerance and acceptance in society. Participation in these so called 'third places' (places outside home and work) provide vital elements of social existence through enabling and liberating experiences (Oldenburg, R. and BRISSETt, D. 1982, Hickman, P. 2010). Public spaces are the ones, where the diverse character of neighbourhoods becomes visible: people experience it and have to deal with it.

The contacts in public spaces between people with different backgrounds can range from the visual interaction to friendly conversation and communal activities. With these experiences, the social production of public spaces in diverse urban societies is an important element of social cohesion - they can generate awareness and acceptance of otherness and multiculturalism (Forrest, R. and Kearns, A. 2001; Peters, K. and De HaAn, H. 2011; Boschman, S. 2012; Wiesemann, L. 2012). In this regard, the quality of public spaces is crucial: safe, comfortable, welcoming places with many facilities are more attractive for different groups of the residents (Myerson, D.L. 2001; Putnam, R. 2007; Peters, K. and de Haan, H. 2011).

At the same time, encountering with diversity in public spaces can also have negative consequences on social cohesion. The different kinds of activities in public spaces can be conflicting with each other, thus, creating divisive forms of identities and lead to intolerance, alienation and isolation (DELANTY, G. 2012; Schмid, K. et al. 2014).

Public spaces are socially produced spaces and conflicted spaces where various values, ideologies and interests are constantly 
(re)negotiated according to the changing power relations in society. Their functions, physical forms, shared meanings and uses can be very diferent (Lefebvre, H. 1991; Zukin, S. 1995; Mitchell, D. 2003; Erôss, Á. et al. 2009; Erôss, Á. 2011; Bodnár, J. 2015). Furthermore, public spaces are increasingly commodified and homogenised in modern capitalist societies (ZuKIN, S. 1991, 1995, 1998). Deviant behaviour and marginal groups (e.g. drug addicts, homeless people etc.) are often excluded through formal and informal restrictions (Belina, B. 2007; Udvarhelyi, É.T. 2014). These actions perceived as a threat to the public and democratic nature of public space (Mitchell, D. and Staehli, A. 2009).

The recognition of hyper-diversity forces us to look differently at the possibilities of living together in a city or a neighbourhood. Mixing groups within a neighbourhood - for example, in terms of income or ethnic descent - may lead to physical proximity of these groups, but because they have different lifestyles, attitudes and activities, these people may actually never meet or never do anything together. Therefore, to gain deeper knowledge on the extent and strength of social networks of the residents of Józsefváros, it is important to analyse the types of activities and interactions of local people and the places where they are performed.

\section{Public spaces in Józsefváros}

Józsefváros has a great variety of public spaces. Green areas are located mainly in the outer parts of the area, while the inner part has a relatively dense street network with smaller squares and parks. The skeleton of the road system was laid down in the second half of the $19^{\text {th }}$ century. Markets have always been important for the local social and economic life and they were often associated with minorities: Jews, Roma people or more recently the Chinese. The traditional market at Teleki Square was established at the end of $19^{\text {th }}$ century and recently went through an extensive redevelopment to maintain and even expand its social and economic functions (focusing on middle-class consumption) (Photo 1, 2). The Four Tigers Market, functioning between 1993 and 2014 was the most important hub of Chinese traders in Budapest, and it had also a social function providing affordable goods for the less affluent people. The market was recently closed because of the illegal trade and the tax evasion of the traders.

Józsefváros - as well as the whole innercity of Budapest - suffered from disinvestment in the decades of communism (Kovács, Z. 1998). This had an effect on public spaces as well: the conditions of local squares, parks and markets deteriorated. In the new millennium several urban regeneration programmes were initiated in central Budapest by the local government and investors (Szemzó, H. and Tosics, I. 2005; Tosics, I. 2005, 2006; KovÁcs, Z. 2006, 2009; LADÁNYI, J. 2014). These programmes aimed at improving the quality of life of the locals and to attract young professionals, tourists, students and also foreigners (CzIrfusz, M. et al. 2015). The transformation of old and creation of new public spaces played an important role in these programmes. In the case-study area the most important project was the so-called Corvin Promenade, a market-led largescale urban rehabilitation project with new apartment buildings, a shopping mall and new public spaces. This project was the latest modification to the historically evolved street pattern. Social rehabilitation also took place in the district with the renewal of several parks and squares - the most prominent among them was the Magdolna Quarter, which is one of the most deprived parts of Józsefváros. At the same time, the so-called Downtown of Europe Programme aimed at upgrading the inner parts of the district in the Palota Quarter, in order to reposition the area in tourism $[1,2]$.

With the physical upgrading of public spaces new practices of spatial regulations were also introduced on national, city and district level. The aim was to keep public spaces secure and to protect the spaces of consumption. The consecutive versions of 


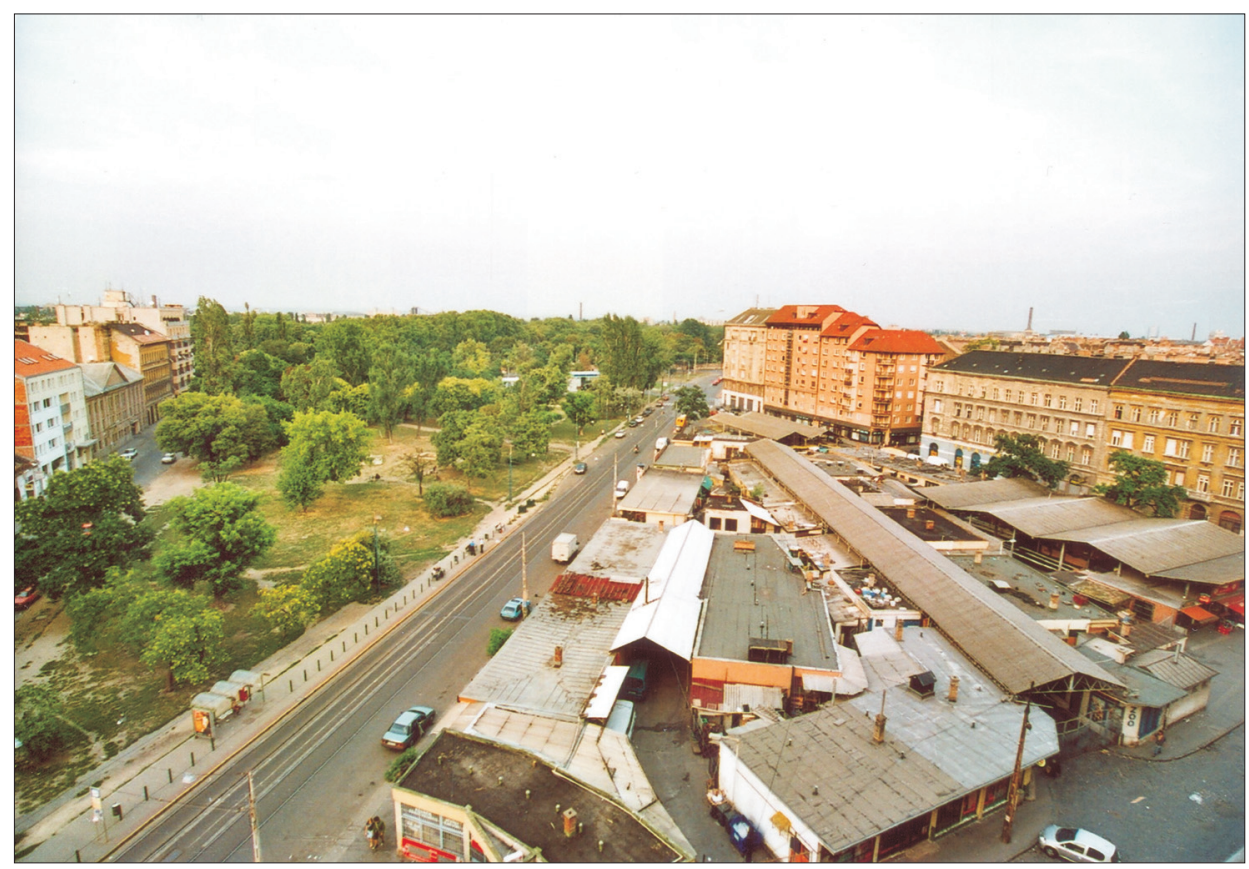

Photo 1. The Teleki Square before renewal (Photo by NYÁRI, GY.)

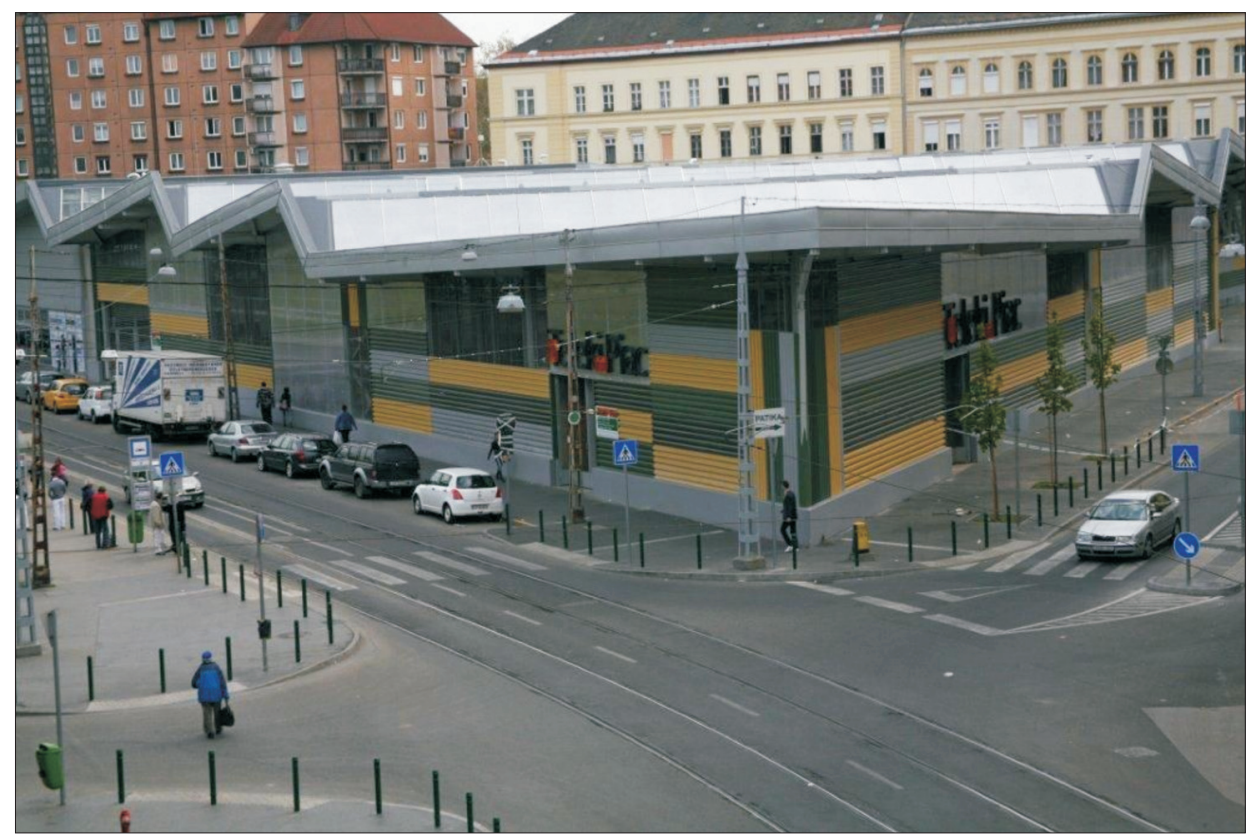

Photo 2. The renewed market at Teleki Square (Photo by NyÁRI, Gy.) 
the Integrated Urban Development Strategies (2008, 2012, 2015) of Józsefváros all targeted to create safe and clean public spaces, to handle the problems related to begging and homelessness, to create quality places for leisure and to expand green areas $[2,3$, $4]$. But there were several anti-homeless and anti-beggar elements of the measurements taken as well - especially in the local legislation (UdvarheLyI, É.T. 2014). In 2010 with the amendments of the Act on Built Environment [5] and the Act on Spatial Development and Planning [6] it became a misdemeanour to use the streets and squares 'improperly' - i.e. begging or sleeping there. The amendment of the Act on Misdemeanours [7] in 2012 provided possibility for municipalities to introduce statutory provisions against homeless people and beggars. In 2012 the Hungarian government made possible for local governments in the fourth amendment of Fundamental Law (the Hungarian Constitution) to forbid living in the streets, underpasses and other public spaces [8]. The aim of these regulations was to create safe, aesthetic urban spaces with the removal of disturbing behaviour.

On the district level, new rules were also introduced to protect the renovated playgrounds and parks; these defined the time periods of use as well as the appropriate behaviour (e.g. no eating in playgrounds, no sleeping or alcohol consumption in parks etc.) in these places (Photo 3). The renewed parks and playgrounds are often fenced to keep away the unwanted users. In some cases, security guards were also hired to enforce the regulations. The local government of Józsefváros also banned eating the food waste from the trash cans in 2010 because 'it is unhealthy and dangerous' [9]. The local government also initiated a referendum in 2011 on begging and homelessness, trying to enforce the previously accepted anti-poor regulations. However, the referendum became unsuccessful, since the voter turnout did not reach the necessary threshold.

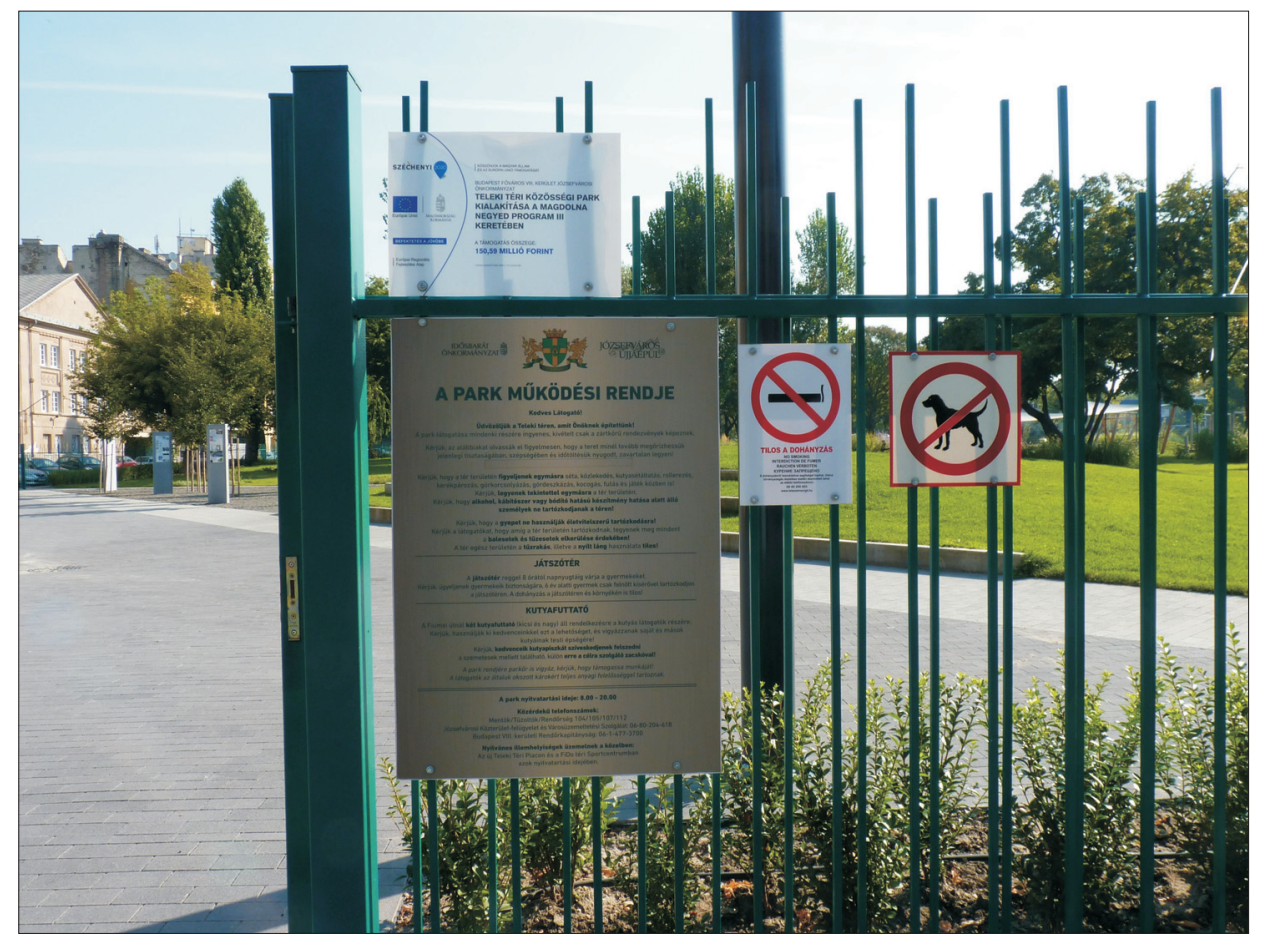

Photo 3. Park regulations at the renewed Teleki Square (Photo by Boros, L.) 
As a bottom-up initiative, community gardening also appeared in the district, using the vacant plots in Józsefváros - the most prominent example being the Leonardo Community Garden. The general objective of Leonardo is to establish and stimulate bottom-up initiatives through community building and to enhance social cohesion. The social background of tenants is very diverse; people with different occupational backgrounds, age, educational level work in the garden. The diversity of participants can be noticed not only in socio-economic, cultural and ethnic terms but also regarding their lifestyle (e.g. residency, gardening experiences and civil leadership). However, the limited availability of plots, the bureaucratic decision-making system and inadequate regulation pose serious challenges to community gardens (BENDE, Cs. and NAGY, Gr. 2015). Due to the ongoing gentrification processes, several quasi-public spaces (bars, restaurants etc.) also appeared in the area as the spaces of consumption, especially in Palota Quarter and Corvin Quarter (Photo 4).

To sum up, the social production of public spaces has changed significantly in our casestudy area. Both the market and the political forces fostered these changes in order to create more liveable and consumable public spaces. On the one hand, it resulted in the creation of aesthetic public spaces, while on the other, the struggle over the production of public space became also intensified after 2000 .

\section{The use of public spaces in Józsefváros: empirical findings}

In this section we present the results of the interviews. What kinds of activities are characteristic for local people, and what kinds of public spaces they use? What kinds of conflicts emerge regarding the use of public spaces and how they perceive the new de-

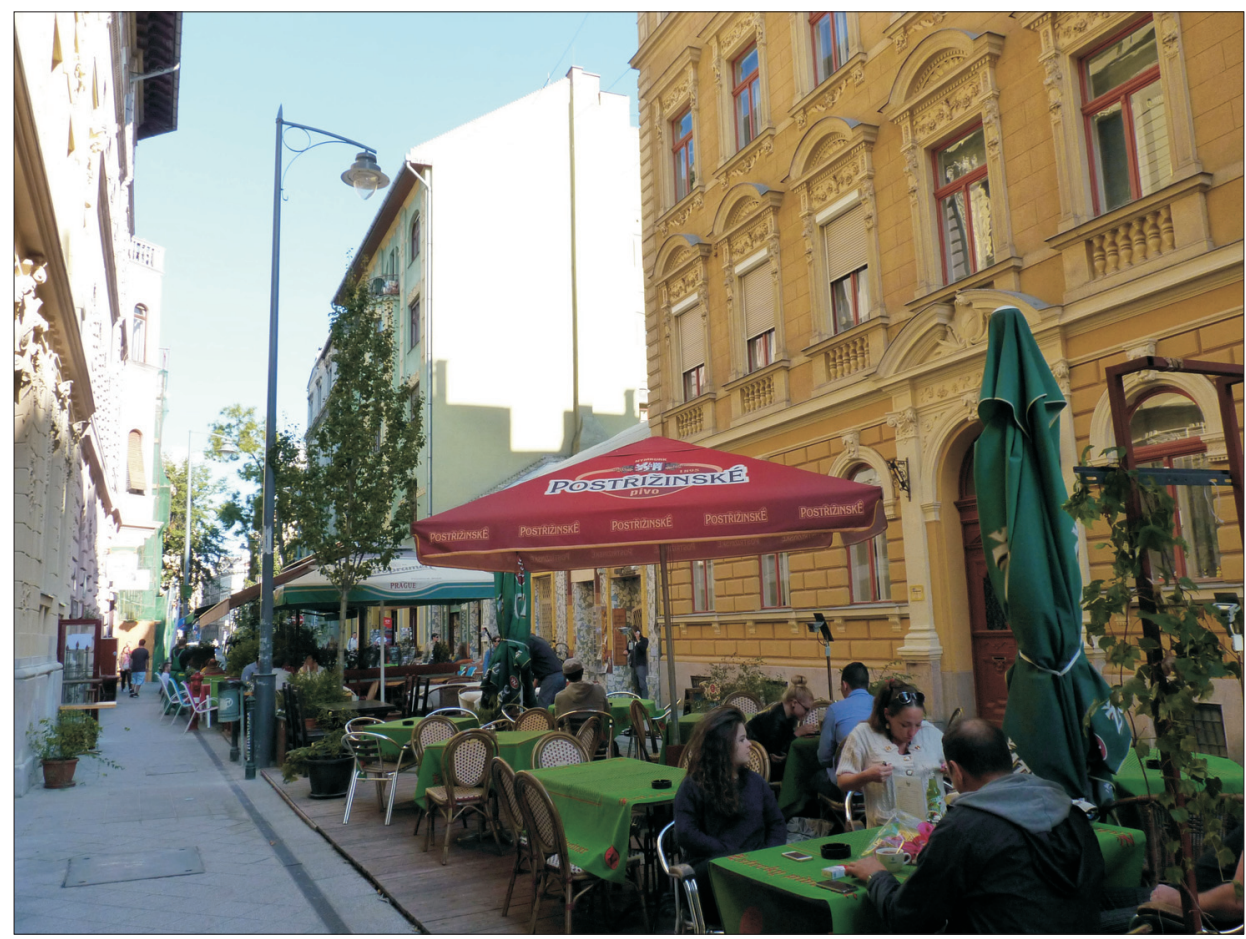

Photo 4. Cafes in the Palota Quarter (Photo by Boros, L.) 
velopments and regulations? We also investigate the free time activities of the residents; what do they do, and with whom do they spend their free time?

According to the respondents' stage in the family life-cycle and their socio-cultural background, four major groups of residents could be identified with distinct variations in daily routine and free-time activities: (1) young singles (below 35); (2) families with children; (3) middle-aged and older people (over 50); (4) migrants and minorities. Within this latter group, three subgroups could be defined: (a) ethnic Hungarians born in the neighbouring states (i.e. Slovakia, Romania) who moved to Hungary after 1990; (b) Roma people being either residents of Budapest already before 1990, or moving to the city after the political changes, (c) international migrants who moved to Hungary/Budapest after 1990 (e.g. Arabs and Chinese).

Among young singles new, flexible forms of work are typical: They are often freelancers or employed in flexible working hours, or telework. Hence the actual place of work is either at home or at shifting locations in Budapest or even beyond (businessmen, agents etc.). Their daily routine is closely linked with other parts of the city, however, their local activity space within Józsefváros is very narrow and it concentrates only to the house, and the surrounding blocks or streets. As the following quote shows, they mix with local people very rarely:

\footnotetext{
"Public spaces are occupied by drug addicts and homeless people, which do not make the neighbourhood attractive for a stroll" (R30, male, 25 years, private entrepreneur: agent of financial products, Hungarian).
}

The daily activity space of people living in families with children is determined by the triangle of home, workplace and institutions of children (kindergarten, school, sport-fields, music school etc.). Their daily activity space is more related to Józsefváros or even to the neighbourhood than in the previous case. Families living in Palotanegyed often take their children to kindergartens or schools in the neighbouring $5^{\text {th }}$ district, where the number of children is much less, and Roma residents are completely missing.

The daily routine is most attached to Józsefváros and the neighbourhood among older people. They use services (health, retail etc.) nearly exclusively in Józsefváros, and typically in the close surroundings. They have also more Church related activities, they spend more time with friends and visit cultural events also more regularly.

The daily routine of people who belong to the group of migrants and minorities is also more strongly linked to certain parts of Józsefváros, most typically the area near the place of residence. They are less skilled, more often unemployed (especially the Roma) or employed by the district for temporary public works. Their daily routine or free time activity is also different from the other three groups because of cultural factors and traditions. For example, in the Roma society women traditionally do not look for permanent job, they are expected to look after the children and the husband, therefore, they often stay at home.

"How should I say? This is different in each Roma family. There are traditions and habits. Some husbands let the wife going out with girl-friend to shop or have a chat. Others say no, you must stay at home, you don't meet others in the town. There are jealous husbands, unfortunately, you know what I mean?" (R44, female, 40 years, public worker, Hungarian-Roma).

The daily routine of individuals is determined most significantly by age, household structure and other socio-economic characteristics (e.g. education, occupation, income). The neighbourhood, its functional (e.g. location of shops, schools) and physical patterns (e.g. green areas), or ethnic characteristics also play a role, though subordinated to the first group of factors.

The four major groups described above have substantial differences regarding their free time activities, too. Older people living in Józsefváros for a long time tend to spend their free time in a narrow geographical area, close to their home (e.g. senior club, market, Church). They built up also the widest net- 
work of friends in the neighbourhood, and most of them maintain strong relations with their neighbours at the house/block level.

The majority of young singles are newcomers in the district. They use public spaces, cultural or leisure institutions of Józsefváros for free time activities relatively rarely. The reasons behind are basically twofold. Firstly, this group has generally a lack of free time. Secondly, as they arrived to Józsefváros more recently, their family, friendly as well as working relations link them to neighbourhoods outside the district. Their typical free time and leisure activity is visiting cafes and 'ruin bars' in the inner-city and most notable in neighbouring Erzsébetváros ( $7^{\text {th }}$ district). Regarding leisure opportunities several respondents mentioned that Józsefváros has changed a lot for the last decade, partly due to the ongoing regeneration activities. There are a lot more attractive places (cafes, bars, clubs etc.) in the district that provide alternatives for young people than before. The growing diversity of free time opportunities was perceived positively by respondents. They also noted that tourists and foreigners living in Budapest permanently are overrepresented in these fashionable places.

The free time activities of people living in families with children are very much determined by the need of their children. Parents adjust their free time schedule to the activities of their children let it be sport, entertainment or hobby. For free time activities, in addition to local parks and squares residents often use public spaces outside the district e.g. in neighbouring Ferencváros (Danube bank), in the $5^{\text {th }}$ district or on the other side of the Danube, Gellért Hill in $11^{\text {th }}$ district.

\footnotetext{
"We often go to Károlyi Garden, partly because everybody from the kindergarten of my kids go there. They live nearby, so for them it is easy. We go there because we always find a mate from the kindergarten, or a couple of acquaintances whom we know, and it is easy to play together... We go to other playgrounds in the surrounding as well, and even to the $9^{\text {th }}$ district, like... Markusovszky Square what we call 'cat square'" (R18, female, 36 years, real estate agent, Hungarian).
}

On the basis of the interviews we can conclude that most of the residents seek free time opportunities also outside the district. The reasons are manifold, e.g. local public spaces often attract people with antisocial behaviour (drug addicts, homeless etc.). The available public spaces and parks often lack conveniences and they are not very much attractive for families with children, or elderly. Segregation plays also a role here, as public spaces in the centre of the district are used mostly by young Roma people, who are noisy and gather in bigger groups, therefore, nonRoma people living in the neighbourhood tend to go to other public spaces, sometimes outside the district limits.

Public spaces were often mentioned in the interviews because of recent local policies aimed at improving security and quality of public spaces. Public spaces were also often mentioned among the positive (e.g. new developments, improving security) or negative (e.g. homeless people, drug users) aspects of the neighbourhood as well. One of the interviewees also highlighted the possible positive effects of renewals on social cohesion:

"... the renovation of square has important role in the cohesion of community. It gives a good feeling to people, because it is important that our children can grow up in a nicer environment." (R21, female, 63 years, old-age pensioner, Hungarian)

According to the interviews there is no particular focal point (i.e. a particularly important) of public spaces in the district, every neighbourhood has its most important place where people gather and interact. At the same time, some of the main roads were mentioned as borders of certain neighbourhoods or the district itself - for example the Grand Boulevard, which is one of the main traffic lines in Budapest. Public spaces that were most often mentioned by respondents can be grouped into the following types: playgrounds, streets, squares, parks, and markets. Shopping malls were mentioned actually fewer than expected - although one of the latest extensive shopping mall developments in Budapest, the so-called Corvin 
Plaza (Photo 5) is located in the central part of Józsefváros. According to the interviews it is considered more of a place of consumption than a place of gathering, recreation and free time. On the other hand, the traditional market on Teleki Square was more often mentioned as a place with not just shopping opportunities but significant social life as well.

"The market on Teleki Square was renovated nicely very recently. Before that I did not go there at all. Instead I went to other markets further from my home because Teleki Square was a complete mess. Now it is really a good place with a fantastic atmosphere. There are shops, coffee houses and sometimes complete bands playing music while people are eating, chatting, shopping" (R48, female, 28 years, student/trainee lawyer, Hungarian).

Based on the interviews playgrounds and parks (Orczy Garden being the most often cited example for the latter) seem to be the most often used and most preferred public spaces in Józsefváros.

In many cases public space is used only for access to work from home. In these cases, they are sites of flows, and not intense interactions. If there are interactions in public spaces it is more probable that they develop between people at similar stages of life cycle (e.g. parents with children, pensioners) or with similar lifestyle (e.g. joggers, skaters, dog owners).

"I would not say that I use them regularly. Of course there were cases when I sat on one of the banks on Rákóczi Square, but I do not have a pet or something. But there are public spaces which are nice and it is a good feeling to go through them" (R3, female, 23 years, student, Hungarian).

The stage in life-cycle or the lifestyle of interviewees have direct influence on the use of public space, activities taking place there, and the level of satisfaction with available public spaces. For example, younger interviewees with children tend to be less satisfied with the quality and quantity of public spaces.

"The most common problem is the lack of clean places and green areas. (...) There are not enough playgrounds: in Palota Quarter there is only one, in Gutenberg Square"

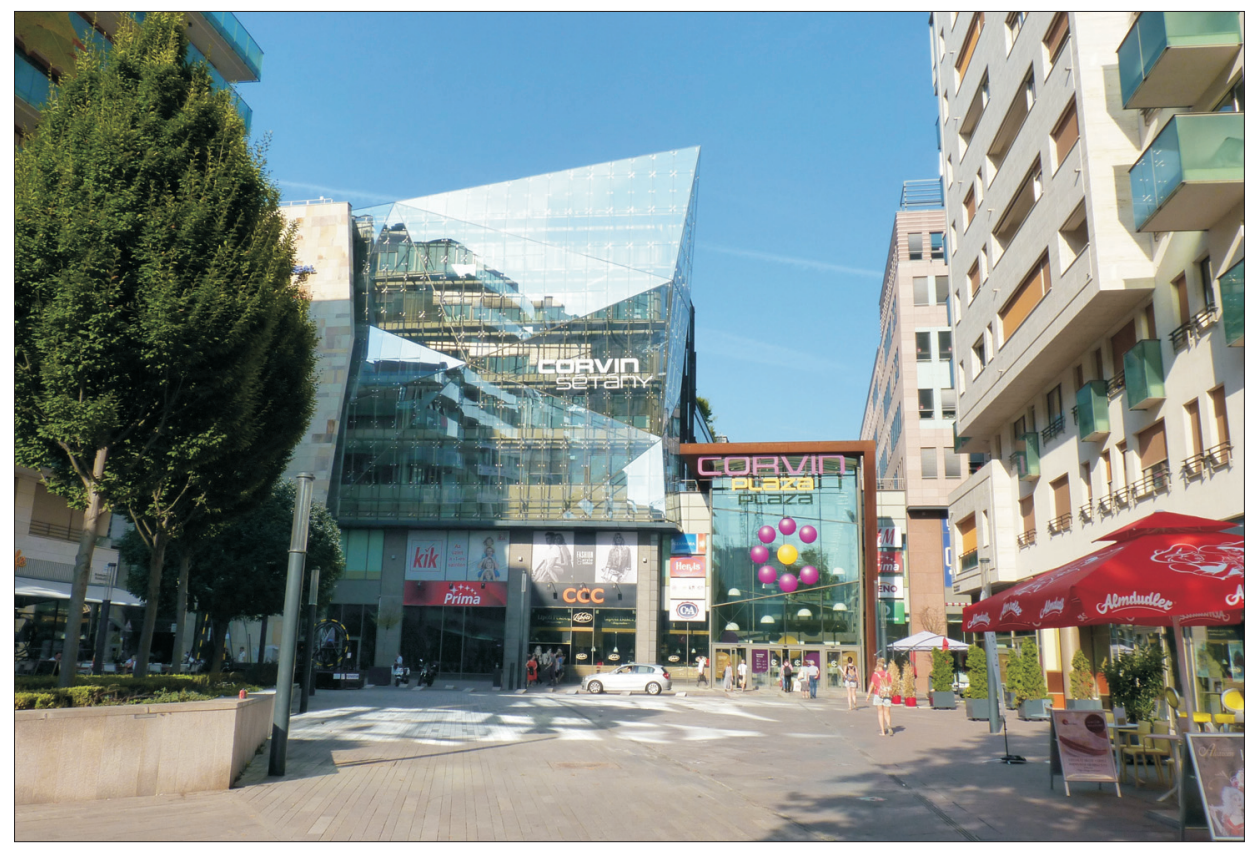

Photo 5. The Corvin Plaza, one of the largest shopping malls in Józsefváros (Photo by Boros, L.) 
(R15, male, 37 years, joint representative of condominiums, Hungarian).

There are three types of conflicts related to public spaces: (1) the issue of who are entitled (or expected) to use them (exclusionary behaviours and policies); (2) conflicts between different users and their activities; and (3) a gap between the needs and the quality and/ or 'quantity' of available public spaces.

Conflicts regarding the use of public spaces were most often mentioned in the case of renewed playgrounds, parks and squares and they were related to homeless people, or - rarely - people from other neighbourhoods. Recently renewed playgrounds are often fenced and guarded to control access and in particular to keep homeless people away:

"There are guards at the renewed playground at Mátyás Square and Kálvária Square as well. I think the reason for this is to keep away drug addicts, homeless people and to prevent vandalism over night" (R28, female, 37 years, community organiser at an NGO, Hungarian-Jewish-Polish).

The situation of public safety, especially drug abuse and the interventions against homeless people, were the most relevant topics for our interviewees. Regardless political orientation respondents seemed to support unequivocally the efforts of the district municipality to create 'order' in the district applying policy measures (e.g. CCTV system controlling public areas, strict local regulation about anti-social behaviour in public spaces). At the same time, judgements on the recently installed CCTV systems were rather contradictory. On the one hand, some people liked it, because they felt it strengthens security in the district:

"Well, the cameras are good things, since we all know that the population of the sistrict is mainly Roma people and we all know the situation in Józsefváros" (R33, male, 37 years, musician, Hungarian-Roma).

On the other hand, some of the interviewees felt that the use of public space became too controlled, thus, they avoid certain places despite the renewal: "...there are these guarded super parks where I do not like to sit because it is not possible to have a beer or to do other kinds of stuff" (R32, male, 34 years, museologist/ webpage designer, Hungarian).

The second type of conflicts often evolves related to dog walking and other uses of public spaces. Different lifestyle groups (e.g. joggers, dog owners, families with children etc.) would like to use the same space for different - and often conflicting - activities. Regulations are set where and when it is possible to walk dogs, but as some of the dog owners neglect the rules they disturb other users and cause problems:

“... this Köztársaság Square, and when I moved here I tried to jogging around the square. I was able to do so about three times then I gave up when a pet dog attacked me and grabbed my pants. And its owner did not react at all" (R50, female, 35 years, researcher, Hungarian).

The gap between the needs of users and the quality of services manifested mostly in the lack of green spaces in the inner, very densely built part of Józsefváros.

"Now, that Köztársaság Square is renewed we often sit there in the summer (...) a lot of youngsters visit this square and there is no public toilet. They renewed it spending more than a billion HUF and there is no toilet" (R3, male, 23 years, student, Hungarian).

The cleanliness and safe use of public spaces seems to be particularly important for the interviewees and it was mentioned in almost every interview, regardless of the age, gender or social status of interviewees. It highlights the importance of clean and attractive public spaces in creation of appropriate spaces for leisure and social interaction. It is important to highlight that the above mentioned conflicts usually do not result in a political action, the individuals concerned just expressed their dissatisfaction in the interviews.

\section{Discussion and conclusions}

The hyper-diversity of Józsefváros is manifested in the everyday activities of local residents since a lot of factors have an influence 
on what and where people do - however, ethnicity still has the most significant role. Prejudice towards Roma influences the activities and the use of public space greatly since several interviewees indicated that they tried to avoid those places where Roma people go. At the same time age, family status, lifestyle and place of residence are also important factors. For example, having children, owning dog or jogging increase the use of public space and the chance of interaction with other residents. As the interviews reflected the most important and most frequently used public spaces in Józsefváros are squares, markets, parks and playgrounds. Although diversity of the district is manifested in the spatial form and use of public spaces, this diversity can be seen among different places rather than within them. The manifestation of diversity can be limited within the public spaces due to local and national regulations which control the time of use and the acceptable behaviour. However, the interviewed residents usually do not oppose these measurements - in some cases they even support them. These measures often have homogenising effect on the public spaces and they exclude or discriminate certain social groups.

Security issues were mentioned in several interviews as motivations for using or not using certain public spaces. Vicinity also has a key role in the use of public spaces: people usually use places which are close to their homes. This works against the mixing of different groups in public spaces. Thus, public spaces of Józsefváros do not function as 'third places' (Oldenburg, R. and Brissett, D. 1982) for some groups (especially for elderly people); they do not participate in activities outside their home or work. According to the interview partners, public spaces are the spaces for movement and places for leisure, recreation - these were the most emphasised functions.

The democratic role of public space was not mentioned by our respondents, probably because the traditional spaces of political protests are located near to the national political institutions and national monuments which are situated outside of the district. No interview partner mentioned directly the renaming of some public spaces which has happened after the 2010 elections, but both the old and new names were used by the respondents. For example, the Pope John Paul II square was sometimes mentioned with its previous name: Republic (Köztársaság) Square. Some interviewees used a shorter form of the name, calling it Pope Square (Pápa tér) - but only for practical reasons, without any political connotation.

A division between local users and tourists, visitors from other parts of Budapest was clearly visible in the most fashionable spaces and also in shopping malls. Local residents barely mentioned shopping malls when they described their daily activities and the use of public space.

As our interviews showed, the fragmented nature of local society is reflected in the use of public spaces as well. Related to public space, diversity and multiculturalism have been mentioned mainly in relation to unusual (comparing to the norms of the ethnic Hungarian majority), 'strange' behaviour of people from various social groups (e.g. the Roma, immigrants). In order to exploit the possibilities of hyper-diversity, the chances of interaction within public spaces should be increased in the future.

Acknowledgements: This project has received funding from the European Union's Seventh Framework Programme for research, technological development and demonstration under Grant Agreement No 319970 - DIVERCITIES. The views expressed in this publication are the sole responsibility of the authors and do not necessarily reflect the views of the European Commission. The work of Lajos Boros was supported by the János Bolyai Research Scholarship of the Hungarian Academy of Sciences. 


\section{REFERENCES}

Atkinson, R. and Kintrea, K. 2000. Owner-occupation, social mix and neighbourhood impacts. Policy and Politics 28. (1): 93-108.

BelinA, B. 2007. From disciplining to dislocation: area bans in recent urban policing in Germany. European Urban and Regional Studies 14. (4): 321-336.

Bende, Cs. and Nagy, Gy. 2016. Közösségi kertek Szegeden - Empirikus vizsgálatok és esettanulmányok (Communitiy gardens in Szeged - an empirical research and case studies). Földrajzi Közlemények 140. (1): 55-72.

Blokland, T. and Nast, J. 2014. From public familiarity to comfort zone: the relevance of absent ties for belonging in Berlin's mixed neighbourhoods. International Journal of Urban and Regional Research 38. (4): 1142-1159.

BLOKLAND, T. and VAN EiJK, G. 2010. Do people who like diversity practice diversity in neighbourhood life? Neighbourhood use and the social networks of 'diversity-seekers' in a mixed neighbourhood in the Netherlands. Journal of Ethnic and Migration Studies 36. (2): 313-332.

Bodnár, J. 2015. Reclaiming public space. Urban Studies 52. (12): 2090-2104.

Boschman, S. 2012. Residential Segregation and Interethnic Contact in the Netherlands. Urban Studies 49. (2): 353-367.

Calhoun, C. ed. 1992. Habermas and the public sphere. Cambridge, MIT Press, $510 \mathrm{p}$.

CANTLE, T. 2012. Interculturalism: For the era of globalisation, cohesion and diversity. Political Insight 3. (3): 38-41.

Castells, M. 2009. The Power of Identity: The Information Age - Economy, Society, and Culture: 2. Oxford, Wiley-Blackwell, 584 p.

Curley, A.M. 2010. Relocating the poor: social capital and neighbourhood resources. Journal of Urban Affairs 32. (1): 79-103.

Czirfusz, M., Horváth, V., Jelinek, Cs., Pósfai, Zs. and Szabó, L. 2015. Gentrification and rescaling urban governance in Budapest-Józsefváros. Intersections 1. (4): 55-77.

Delanty, G. 2012. A cosmopolitan approach to the explanation of social change: social mechanisms, processes, modernity. Sociological Review 60. (2): 333-354.

Dudás, G. and Pernyész, P. 2011. A globális városok térkapcsolatának vizsgálata légi közlekedési adatok felhasználásával (The analysis of spatial connections between global cities using air traffic data). Tér és Társadalom 25. (4): 81-105.

Eraydin, A., Tasan-Kok, T. and Vranken, J. 2010. Diversity matters: immigrant entrepreneurship and contribution of different forms of social integration in economic performance of cities. European Planning Studies 18. (4): 521-543.
Erôss, Á. 2011. Contested spaces. Ethnic visibility in the city of Oradea. In Critical spaces: contemporary perspectives in urban, spatial and landscape studies. Ed.: Calcatinge, A., Münster, LIT Verlag, 69-87.

Erôss, Á., Tátrai, P. and Kocsis, K. 2009. Mapping of symbolic occupation of urban space: the case of the street-names in Oradea. In Descriptio Transylvaniae: International Conference on History of Cartography and Historical Geography. Eds.: Csiki, B. and Bartos-Elekes, Zs., Cluj-Napoca, Cholnoky Jenő Geographic Society-Babeş-Bolyai University, Faculty of Geography, 133-143.

Forrest, R. and Kearns, A. 2001. Social cohesion, social capital and the neighbourhood. Urban Studies 38. (12): 2125-2143.

Goffman, E. 1959. The presentation of Self in everyday life. London, Penguin Books, 251 p.

Habermas, J. 1989. The Structural Transformation of the Public Sphere: An Inquiry into a category of Bourgeois Society. Cambridge, Polity, 328 p.

Harvey, D. 2005. The political economy of public space. In The Politics of Public Space. Eds.: Low, S. and Sмiтн, N. New York, Routledge, 17-34.

Hickman, P. 2010. Neighbourhood Infrastructure, 'Third Places' and Patterns of Social Interaction. Research Paper No. 4. Sheffield, Centre for Regional Economic and Social Research, Hallam University, $46 \mathrm{p}$.

Kovács, Z. 1998. Ghettoization or gentrification? Postsocialist scenarios for Budapest. Netherlands Journal of Housing and the Built Environment 13. (1): 63-81.

KovÁcs, Z. 2006. Social and Economic Transformation of Historical Districts in Budapest. In Social changes and social sustainability in historical urban centres. Eds.: Enyedi, Gy. and Kovács, Z., Pécs, Centre for Regional Studies HAS, 39-64.

KovÁcs, Z. 2009. Social and economic transformation of historical neighbourhoods in Budapest. Tijdschrift voor Economische en Sociale Geografie / Journal of Economic and Social Geography 100. (4): 399-416.

LADÁNYI, J. 2014. Changing patterns of social and ethnic residential segregation in Budapest. International Journal of Urban and Regional Research 13. (4): 555-572.

Lees, L. 2008. Gentrification and social mixing: towards an inclusive urban renaissance? Urban Studies 45. (12): 2449-2470.

Lefebvre, H. 1991. The production of space. Oxford, Basil Blackwell, 464 p.

Mitchell, D. 1995. The end of public space? People's Park, definitions of the public, and democracy. Annals of the Association of American Geographers 85. (1): 108-133.

Mitchell, D. 2003. The right to the city: Social justice and the fight for public space. New York, The Guilford Press, 270 p. 
Mitchell, D. and Staehli, A. 2009. Public space. In International Encyclopedia of Human Geography, Vol. 8. Eds.: Kitchin, R. and Thrift, N., Amsterdam, Elsevier, 511-516.

Myerson, D.L. 2001. Sustaining urban mixed-income communities: the role of community facilities. A land use policy report prepared for the Urban Land Institute. Chicago, Charles H. Shaw Annual Forum on Urban Community Issues, $12 \mathrm{p}$.

Nathan, M. 2006. The economics of super-diversity: Findings from British cities, 2001-2006. SERC Discussion Paper 68. London, SERC, 49 p.

Nielsen, S. 2013. Public Space - A Concept under Negotiation. In A Space Called Public. Eds.: Elomgren, M. and Dragset, I., Köln, Walther König Verlag, 228-248.

Oldenburg, R. and Brissett, D. 1982. The third place. Qualitative Sociology 5. (4): 265-284.

Peters, K. and De HaAn, H. 2011. Everyday spaces of inter-ethnic interaction: the meaning of urban public spaces in the Netherlands. Leisure/Loisir 35. (2): 169-190.

Putnam, R. 2007. E pluribus unum: Diversity and community in the twenty-first century. The 2006 Johan Skytte Prize lecture. Scandinavian Political Studies 30. (2): 137-174.

Schmid, K., Al Ramiah, A. and Hewstone, M. 2014. Neighbourhood ethnic diversity and trust: the role of intergroup contact and perceived threat. Psychological Science 25. (3): 665-674.

Sennett, R. 2002. The Fall of Public Man. London, Penguin, $416 \mathrm{p}$.

Sheller, M. and URRY, J. 2006. The new mobilities paradigm. Environment and Planning A, 38. (2): 207-226.

Syrett, S. and Sepulveda, L. 2011. Realising diversity dividend: Population diversity and economic development. Environment and Planning A. 43. (2): 487-504.

Szemzó, H. and Tosics, I. 2005. Hungary. In Urban Issues and Urban Policies in the New EU Countries. Eds.: Van Kempen, R., Vermeulen, M. and BaAn, A., Ashgate, Euricur, 37-60.

Tasan-KoK, T., Van Kempen, R., Raco, M. and Bolt, G. 2014. Towards hyper-diversified European cities: a critical literature review. Utrecht, Utrecht University, Faculty of Geosciences, 85 p.

Tosics, I. 2005. The post-socialist Budapest: the invasion of market forces and the attempts of public leadership. In Transformation of Cities in Central and Eastern Europe: Towards Globalization. Eds.: Hamilton, F.E.I., Dimitrowska-Andrews, K. and Pichler-Milanovic, N., Tokyo, UN University Press, 248-280.

Tosics, I. 2006. Spatial restructuring in post-socialist Budapest. In The Urban Mosaic of Post-Socialist Europe. Space, Institutions and Policy. Eds.: Tsenkova, S. and Nedović-Budić, Z., Heidelberg, PhysicaVerlag, 131-150.
Udvarhelyi, É.T. 2014. “If we don't push homeless people out, we will end up being pushed out by them": The criminalization of homelessness as state strategy in Hungary. Antipode 46. (3): 816-834.

Urry, J. 2007. Mobilities. Cambridge, Polity, 336 p.

Van Beckhoven, E. and Van Kempen, R. 2003. Social effects of urban restructuring: a case study in Amsterdam and Utrecht, the Netherlands. Housing Studies 18. (6): 853-875.

VAn Kempen, R. and Wissink, B. 2014. Between spaces and flows: towards a new agenda for neighbourhood research in an age of mobility. Geografiska Annaler: Series B. 96. (2): 95-108.

VedréDI, K. 2014. Social perception of public space developments - The case of Saint Stephen Square, Szeged, Hungary. European Journal of Geography 5. (3): 60-72.

Vertovec, S. 2007. Super-diversity and its implications. Ethnic and Racial Studies 30. (6): 1024-1054.

Wiesemann, L. 2012. Public spaces, social interaction and the negotiation of difference. MMG Working Paper 1208. Göttingen, Max Planck Institute for the Study of Religious and Ethnic Diversity, 26 p.

Wissink, B. and Hazelzet, A. 2012. Social networks in 'neighbourhood Tokyo'. Urban Studies 49. (7): 1527-1548.

Zukin, S. 1991. Landscapes of power: from Detroit to Disney World. Berkeley, University of California Press, $338 \mathrm{p}$.

Zukin, S. 1995. The cultures of cities. Oxford, Blackwell Publishing, $338 \mathrm{p}$.

ZuKIN, S. 1998. Urban lifestyles: diversity and standardisation in spaces of consumption. Urban Studies 35. (5-6): 825-839.

\section{OTHER SOURCES}

[1] Hungarian Central Statistical Office (2011). Population Census 2011 - Detailed tables. Accessed at http://www.ksh.hu/nepszamlalas/detailedtables. 2 October 2015.

[2] Józsefváros. Integrált Városfejlesztési Stratégia (2008, 2012). Budapest, Rév 8 Józsefvárosi Rehabilitációs és Városfejlesztési ZRt. Accessed at: http://www.terport.hu/webfm_send/3186 4 August 2016.

[3] Pest-budapest Konzorcium 2015. Józsefváros Integrált Településfejlesztési Stratégia - Megalapozó vizsgálat (Józsefváros Integrated Urban Development Strategy - Baseline Report). Budapest Főváros VIII. kerület Józsefvárosi Önkormányzat, Budapest.

[4] Józsefváros Zöldfelület Fenntartási és Környezetvédelmi Koncepciója, 2014. (Green Area Sustainability and Environmental Protection Concept of Józsefváros, 2014). Budapest Főváros VIII. kerület Józsefvárosi Önkormányzat, Budapest. 
[5] 1997. évi LXXVIII. törvény az épitett környezet alakitásáról és védelméról (Act LXXVIII. of 1997 on the development and protection of built environment). Accessed at http://net.jogtar.hu/jr/gen/hjegy_doc. cgi?docid $=99700078$. TV. 5 August 2016

[6] 1996. évi XXI. törvény a területfejlesztésről és a területrendezésröl (Act XXI. of 1996 on regional development and planning). Accessed at http://net. jogtar.hu/jr/gen/hjegy_doc.cgi?docid=99600021. TV 5 August 2016

[7] 2012. évi II. törvény a szabálysértésekról, a szabálysértési eljárásról és a szabálysértési nyilvántartási rendszerröl (Act II. of 2012 on Misdemeanours). Accessed at http://net.jogtar.hu/jr/gen/hjegy_doc. cgi?docid=A1200002.TV. 09 December. 2013.
[8] Magyarország alaptörvénye 2011.(The Fundamental Law of Hungary, 2011). Accessed at http://www. kormany.hu/download/2/ab/30000/Alap_angol. pdf, 6 September 2013.

[9] Józsefuárosban tilos kukázni! (Rummaging is forbidden in Józsefváros!) Accessed at http://jozsefvaros. hu/hir/374/jozsefvarosban_tilos_kukazni/accessed: 20 May 2016 